\title{
Myth-Making and the Politics of Nationality in Narratives of J.S. Bach's 1717 Contest with Louis Marchand
}

\section{Christopher Wiley (University of Surrey, UK)}

The increasing scholarly attention paid to musical biography across the past few decades has brought to attention many aspects of both the processes of myth-making that have historically operated within the genre as well as the intervention of the politics of nationality in narratives of composers' lives. The nature of biographical mythologization has been explored within the context of single-composer book projects including, amongst others, William Stafford's The Mozart Myths (1991), Alessandra Comini's The Changing Image of Beethoven (1987), and David Hunter's The Lives of George Frideric Handel (2015), while my own full-length study of musical biography (2008) has rigorously investigated the nature of mythology itself through the comparative examination of life-writing across a range of composers, countries, and centuries. ${ }^{1}$ Hans Lenneberg (1988) has identified nationality as a factor influencing major music-biographical sources at least as far back as eighteenth- and early nineteenth-century lexicography, and my research on the origins of the stillcurrent “Master Musicians" series (2003) provides systematic demonstration of the

1 William Stafford, The Mozart Myths: A Critical Reassessment (Stanford, CA: Stanford University Press, 1991), published in the UK as Mozart's Death: A Corrective Survey of the Legends (London: Macmillan, 1991). Alessandra Comini, The Changing Image of Beethoven: A Study in Mythmaking (New York: Rizzoli, 1987). David Hunter, The Lives of George Frideric Handel (Woodbridge, Suffolk: The Boydell Press, 2015). Christopher Wiley, Re-writing Composers' Lives: Critical Historiography and Musical Biography, 2 Vols. (PhD dissertation, University of London, 2008), available online at <http://digirep.rhul.ac.uk/items/51c986f5-ea02-d3b8-03e26ab2b962a61f/1/>. The latter incorporates preliminary discussion of the case study presented in this chapter, versions of which have been delivered at the Institute of Musical Research, London (10 April 2015), Faculty of Music, Oxford (16 June 2015), and University of Amsterdam (26 January 2018). 
ways in which authors endeavoured to emphasize the relevance of their subjects to late Victorian Britain, as well as the documentary value consequently embodied by such texts as reflections of the priorities and sensibilities of specific reading communities. ${ }^{2}$ Scholars such as Toby Thacker (2006) and Jolanta T. Pekacz (2006) have investigated analogous political appropriations of canonical composers including Bach, Handel, and Chopin in ideological contexts ranging from the German Democratic Republic to nineteenth-century Poland; and Jeremy Dibble's examination (2001) of the first edition of Grove's Dictionary (1879-90) has revealed its English biases in terms both of content and scholarship. ${ }^{3}$

Less frequently has the interplay been explored between the processes of mythologization within musical biography, and the national politics that underpinned the distinctive ways in which authors were led to recount certain illustrative episodes that, over time, have become embellished, distorted, and even debunked, such that they accrued meaning progressively as they were appropriated to perform cultural work at particular times and places. I have elsewhere explored

2 Hans Lenneberg, Witnesses and Scholars: Studies in Musical Biography (New York: Gordon and Breach, 1988), 18-37 and 66-81. Christopher Wiley, “'A Relic of an Age Still Capable of a Romantic Outlook': Musical Biography and The Master Musicians Series, 1899-1906," Comparative Criticism 25 (2003): 161-202. See further, my forthcoming book Musical Biography as a Historical and Literary Genre: The Master Musicians Series, 18991906.

3 Toby Thacker, “'Renovating” Bach and Handel: New Musical Biographies in the German Democratic Republic" and Jolanta T. Pekacz, "The Nation's Property: Chopin's Biography as a Cultural Discourse," in Musical Biography: Towards New Paradigms edited by Jolanta T. Pekacz (Aldershot: Ashgate, 2006), 17-41 and 43-68, respectively. Jeremy Dibble, “Grove's Musical Dictionary: A National Document,” in Musical Constructions of Nationalism: Essays on the History and Ideology of European Musical Culture 1800-1945 edited by Harry White and Michael Murphy (Cork: Cork University Press, 2001), 33-50. A Dictionary of Music and Musicians (A.D. 1450-1889) by Eminent Writers edited by George Grove, 4 Vols. (London: Macmillan, 1879-90). 
the enduring cultural value of the comparatively under-theorized genre of biographical anecdote: those stories that have customarily been retold in a range of life-writing contexts across history, remaining much cherished by authors as a means both to illustrate their subjects' extraordinary abilities and, more broadly, to stake their claim within music history. ${ }^{4}$ One recognizable subcategory to have emerged within musical biography concerns those tales that Sarah Clemmens Waltz, following Kris and Kurz's still-useful experimental study of biographies within the field of art history, has aptly called the "obligatory musical duel for virtuosos," competitions that historically took place between great performers of their day in an ostensible bid to determine which out of two musical titans might be deemed better than the other. ${ }^{5}$ The biographical episode at the heart of this chapter, the contest that was to have taken place in Dresden in Autumn 1717 between J.S. Bach and Louis Marchand, may be one of the best known. It is, after all, almost solely responsible for the name and reputation of Bach's rival - the celebrated French keyboardist and composer then active at the Dresden court-not having been entirely forgotten to history, at least in Anglo-American musical discourses, and it soon attained widespread circulation. Such events were comparatively common during the eighteenth century, one between Handel and Domenico Scarlatti having occurred in

4 See Christopher Wiley, "Biography and Life-Writing," in The Oxford Handbook of Music and Intellectual Culture in the Nineteenth Century edited by Paul Watt, Sarah Collins, and Michael Allis (Oxford: Oxford University Press, 2019).

5 Ernst Kris and Otto Kurz, Die Legende vom Künstler: Ein historischer Versuch (Vienna: Krystall Verlag, 1934), revised by Otto Kurz as Legend, Myth, and Magic in the Image of the Artist: A Historical Experiment translated by Alastair Laing and Lottie M. Newman (New Haven, CT: Yale University Press, 1979). Sarah Clemmens Waltz, "The Uses of Apocrypha," in (Auto)Biography as a Musicological Discourse edited by Tatjana Markovic and Vesna Mikic (Beograd: Fakultet Muzicke Umetnosti, 2010), 84-96, at 85. 
Rome around a decade previously, according to the former's biographer, John Mainwaring; ${ }^{6}$ that between Mozart and Clementi, held before Emperor Joseph II and other dignitaries at Vienna in 1781, constitutes a historically famous later example. But perhaps the most significant parallel to Bach and Marchand's competition, as Christoph Wolff has observed, was yielded by another that had previously taken place at the Dresden court, between J.J. Froberger and Matthias Weckmann, probably around 1649-50.7

The contest between Froberger and Weckmann, unlike that of Bach and Marchand, appears to have been an amicable one, which, as might be expected of (and hoped for in) a biographical story in which leading musicians cross paths with one another, precipitated lasting contact between them. Similarly, Mainwaring's account leaves no doubt in the reader's mind that Handel and Scarlatti regarded one another highly in consequence of their meeting. As biographical anecdote, Bach and Marchand's story stands out even further, and therefore presents itself as particularly worthy of study as an exemplar of the cultural work performed by composer life-writing in relation to national politics, since even the early accounts are widely divergent in their details of the episode. This situation contrasts sharply with the significant level of consonance between the reports left by both Mozart and Clementi (the latter mediated via his pupil, Ludwig Berger) of their own competition, 8 and, remarkably, it came about even despite several of the earliest

6 [John Mainwaring], Memoirs of the Life of the Late George Frederic Handel (London: Dodsley, 1760), 59-62.

7 Christoph Wolff, Johann Sebastian Bach: The Learned Musician (Oxford: Oxford University Press, 2000), 180.

8 W.A. Mozart, letter to Leopold Mozart, 16 January 1782, in The Letters of Mozart and his Family translated and edited by Emily Anderson, rev. 3rd edn. by Stanley Sadie and Fiona Smart (London: Macmillan, 1985), 792-3, at 793. Ludwig Berger, Caecilia 10 (1829): 238. A good summary of the event and its documentary sources is 
accounts having claimed the authority of either Bach or his sons for their version of events. Even that assertion was not in itself unproblematic, since some of those same sources also inform the reader that the modest Bach rarely spoke of the episode unless prompted or pressed to do so. ${ }^{9}$

Werner Breig's meticulous examination of the eighteenth-century sources for this episode has previously called attention both to the significant number of variant early accounts of Bach's competition with Marchand, and to the relationships between these different versions of the popularly retold anecdote. ${ }^{10}$ In terms of the later development of biographical writing on both composers, the most significant of these early reports include those by J.A. Birnbaum (1739), Jakob Adlung (1758), and F.W. Marpurg (1786), each of whom may have received the story directly from Bach; ${ }^{11}$ Bach's obituary notice (the so-called "Nekrolog"), co-authored by C.P.E. Bach given in Leon Plantinga and Alan Tyson, "Clementi, Muzio," The New Grove Dictionary of Music and Musicians edited by Stanley Sadie and John Tyrrell, 2nd edn., 29 Vols. (London: Macmillan, 2001), Vol. 6, 39-46, at 40.

9 See “A Comparison of Bach and Handel [by Carl Philipp Emanuel Bach?] ... Excerpt from a Letter of February 27, 1788," in The New Bach Reader: A Life of Johann Sebastian Bach in Letters and Documents edited by Hans T. David, Arthur Mendel, and Christoph Wolff (New York: Norton, 1998), 400-9, at 408; and J[ohann] N[icolaus] Forkel, Ueber Johann Sebastian Bachs Leben, Kunst und Kunstwerke (Leipzig: Hoffmeister und Kühnel, 1802), translated as “On Johann Sebastian Bach's Life, Genius, and Works," in The New Bach Reader edited by David, Mendel, and Wolff, 417-82, at 459.

10 Werner Breig, “Bach und Marchand in Dresden: Eine überlieferungskritische Studie," Bach-Jahrbuch 84 (1998): $7-18$.

11 Johann Abraham Birnbaum, “Vertheidigung seiner unparteyischen Anmerkungen über eine bedenkliche Stelle in dem sechsten Stücke des critischen Musikus, wider Johann Adolph Scheibens Beantwortung derselben," Des Critischen Musikus 3 ([Leipzig], 1739), 899-1031, at 981-2, reprinted in Bach-Dokumente edited by Werner Neumann and Hans-Joachim Schulze, 3 Vols. (Bärenreiter: Kassel, 1963-72), Vol. 2 (1969), 340-1 and translated in The New Bach Reader edited by David, Mendel, and Wolff, 79-80. J. Adlung, Anleitung zu der musikalischen Gelahrtheit (Erurt: Jungnicol, 1758), 690, reprinted in Bach-Dokumente edited by Neumann and Schulze, Vol. 3 (1972), 121-2. [Friedrich Wilhelm Marpurg], Legende einiger Musikheiligen: Ein Nachtrag zu den musikalischen Almanachen und Taschenbüchern jetziger Zeit (Cölln: Hammer, 1786), 291-3, reprinted in Bach- 
and another student of his father's, J.F. Agricola (1754), in which the anecdote appeared as one of just five told of the recently deceased composer; ${ }^{12}$ and J.N. Forkel's biography (1802), based on comprehensive information garnered from Bach's two eldest sons, Wilhelm Friedemann Bach and C.P.E. Bach, with whom Forkel had been in contact since first planning to write an account of their father's life in the 1770s. ${ }^{13}$ The historical writings of Burney (1773) and Hawkins (1776) also include versions of the episode, the latter of which (and possibly also the former) written on the authority of Bach's youngest son, Johann Christian Bach, by then firmly established in London, who himself would have received the story at secondhand, having not been born until 1735, eighteen years after the event took place. These two sources differ from all other accounts in a number of respects, yielding the distinctive English variant (“Überlieferung”) previously isolated by

Dokumente edited by Neumann and Schulze, Vol. 3, 423-5; two pertinent earlier writings by Marpurg are discussed below, n. 20. Christoph Wolff has parenthetically speculated that Birnbaum's account may have even been written “under Bach's supervision;" Wolff, “Johann Sebastian Bach," The New Grove Dictionary of Music and Musicians edited by Sadie and Tyrrell, Vol. 2, 309-82, at 316. Presumably this suggestion was made on the basis of Bach's having overseen Birnbaum's subsequent, lengthy defence of the composer; see “'Impartial Comments on a Questionable Passage in the Sixth Number of Der Critische Musicus,' by Johann Abraham Birnbaum (1738)", in The New Bach Reader edited by David, Mendel, and Wolff, 338-48.

12 [C.P.E. Bach and J.F. Agricola,] “Denkmal dreyer verstorbenen Mitglieder der Societät der musikal. Wissenschafften...", in [L.C. Mizler (ed.)], [Neu eröffnete] Musikalische Bibliothek 4/1 (1754): 158-76 ["Nekrolog"], reprinted in Bach-Dokumente edited by Neumann and Schulze, Vol. 3, 80-92, at 83-4. For modern translation, see “'The World-Famous Organist, Mr. Johann Sebastian Bach, Royal Polish and Electoral Saxon Court Composer, and Music Director in Leipzig', obituary by Carl Philipp Emanuel Bach and Johann Friedrich Agricola (1750, published 1754)," in The New Bach Reader edited by David, Mendel, and Wolff, 297307, at 300-2. The significance of the "Nekrolog" to mythology in/and musical biography, in terms of furnishing life-writing on Bach with five central anecdotes, is extensively discussed in Wiley, Re-writing Composers' Lives, Vol. 1, 20-178.

13 Forkel, “On Johann Sebastian Bach's Life, Genius, and Works” (for full citation, see above, n. 9), 427-8. 
Breig, and therefore standing apart from the paths that Bach biography was principally to take in the long nineteenth century. ${ }^{14}$

While the appearance of discrepancies, even extensive ones, between early accounts of a biographical anecdote is hardly distinctive in and of itself, this episode is especially instructive since the existence of such variations led later authors to inherit particular versions of the story as well as enabling them to craft their narratives selectively according to their own sympathies, in terms of the subject of their biographical writing (that is, whether its focus fell on Bach or Marchand) but also, more crucially, of the politics of nationality. In general, such tales of contests between two accomplished personages lend themselves ideally to appropriation beyond the competitors themselves, as well as to broader allegorical interpretations. This one was certainly no exception in that it spoke, at least implicitly, to prevailing debates concerning whether German or French music was pre-eminent.

Consequently, conflicting versions of the same story have co-existed within musicbiographical writing throughout much of the nineteenth and twentieth centuries. Whereas Breig's study of the sources extended only as far as 1802, taking Forkel's biography as his historical end-point, my approach has been to trace the subsequent development of the episode in life-writing up to the present time, in order to offer a fuller sense of the cultural implications of the longitudinal trajectories it followed as

14 Charles Burney, The Present State of Music in Germany, The Netherlands, and United Provinces. Or, The Journal of a Tour through those Countries, undertaken to collect Materials for A General History of Music, 2 Vols. (London: Becket, Robson, and Robinson, 1773), Vol. 2, 81-2. Sir John Hawkins, A General History of the Science and Practice of Music, 5 Vols. (London: Payne, 1776), Vol. 5, 255. Breig, “Bach und Marchand in Dresden," 16-17 (see further, n. 20 below). Breig's article also identified several additional eighteenth-century sources for the episode, which have been tacitly omitted from the above discussion for their dearth of explicitly discernible impact on later biographical writing. 
well as its striking changes of direction. At the same time, my examination offers broader insights into the nature of the genre of musical biography given the widespread practices of retailing this anecdote at length even though the competition was at best a stalemate (at worst, a non-event), leading authors to adopt additional discursive strategies in order to lend such a passive tale the emphasis it required to function, even awkwardly, as an illustration of either Bach's or Marchand's greatness. Finally, the history of its unfolding over time sheds rare light on the process of biographical myth-making itself given that it incorporates an exceptional historical instance in which a particular author - namely Philipp Spitta, writing in his milestone multi-volume life of Bach (1873-80) - explicitly and knowingly endeavoured to intervene in the agencies by which a story becomes mythologized. ${ }^{15}$

The analysis that follows knowingly maintains a certain emphasis on canonical texts drawn from the plethora of accounts of Bach's life to have emerged over the decades, since these are the ones that have had the greatest potential to exert influence in shaping the course of subsequent music-historical writing on both Bach and, by extension, Marchand. Evaluation of the totality of the narratives of the episode would lie well beyond the scope of this chapter, notwithstanding that the

15 Philipp Spitta, Johann Sebastian Bach, 2 Vols. (Leipzig: Breitkopf und Härtel, 1873-80), translated by Clara Bell and J.A. Fuller Maitland as Johann Sebastian Bach: His Work and Influence on the Music of Germany, 1685-1750, 3 Vols. (London: Novello, 1884-5). Spitta included in an appendix an in-depth assessment of the early accounts of Birnbaum, Adlung, the "Nekrolog," and Marpurg, in that order (see above, nn. 11-12, for citations), generously quoting and paraphrasing from each such that his endnote occupied more space than his own retelling of the episode; see Vol. 1, 644-7 (cf. Vol. 1, 815-18 of the original German edition). Further evaluation of the sources was later provided by Charles Sanford Terry, Bach: A Biography (London: Oxford University Press, 1928), 110-12. 
volume of literature that has appeared on Bach relative to Marchand is so heavily weighted in favour of the former that to attempt systematic exegesis would inevitably give rise to a markedly one-sided presentation of the richness of the mythological nexus that has developed in parallel life-writing on the two musicians. To supplement the consciously non-exhaustive commentary on this elaborate mythology given below, Table 1 identifies more systematically the main themes that emerge from comparative examination of a range of retellings of the story in lifewriting on Bach together with the sources in which they appear, including, for breadth, some historically significant texts not otherwise referenced in the course of this chapter; citations for each are provided in Table 2. The appended tables hence provide a visual frame of reference for the relationships between different accounts, together with an indication of their bases in earlier sources where this may reasonably be determined. In contrast with Breig's article, in which the specific narrative presented by the "Nekrolog" was itemized into thirteen successive elements ("Einzelemente") apparently given equal weight,16 my intentions have instead been to illustrate the hierarchical relationships between different strands of the myth as it continued to develop across time, by way of probing the extent to which those themes and sub-themes flourished within-or were rejected bysubsequent biographical writing on both artists. The story's chief components are labelled themes 1-9 in Table 1, with sub-themes (possible outcomes of the main theme, as put forward by different authors) gathered together into cognate groups underneath them, distinguished using a suffixed letter (such as theme 1(a)-1(e)); 
Table 1: Themes in Selected Biographical Accounts of the 1717 Contest between J.S. Bach and Marchand

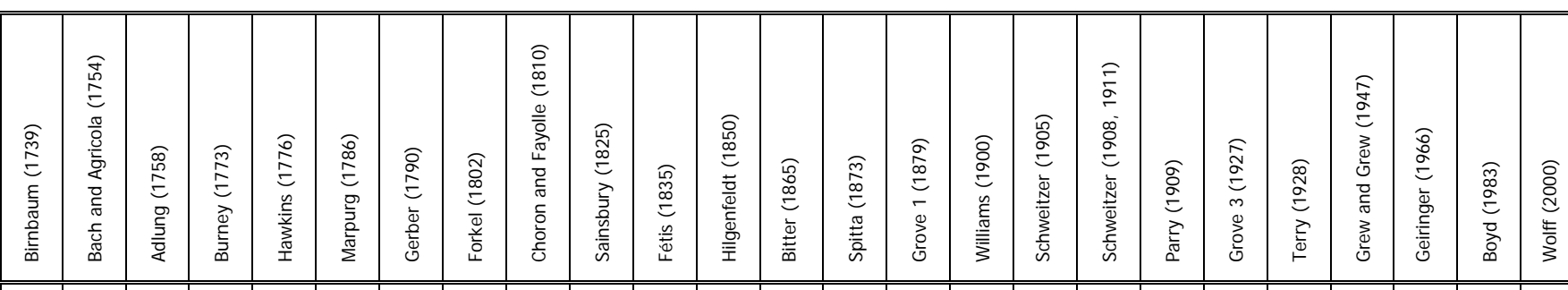

\begin{tabular}{|c|c|c|c|c|c|c|c|c|c|c|c|c|c|c|c|c|c|c|c|c|c|c|c|c|c|}
\hline $\begin{array}{l}\text { 1. Who brought about the contest (Volumier/the King) } \\
\text { (a) Volumier (Dresden Concertmeister) brought about the contest }\end{array}$ & & $\checkmark$ & & & & $\checkmark$ & $\checkmark$ & $\checkmark$ & $\checkmark$ & $\checkmark$ & $\checkmark$ & $\checkmark$ & $\checkmark$ & & & & & $\checkmark$ & & $(v)$ & {$[\sqrt{ }]$} & & & $\checkmark$ & $\checkmark$ \\
\hline (b) The King of Poland (=Elector of Saxony) brought about the contest & & & & $(v)$ & $\checkmark$ & & & & & & & & & & & & & & & & & & & & \\
\hline $\begin{array}{l}\text { (c) The King, while not bringing about the contest, nonetheless endorsed it } \\
\text { (a) }\end{array}$ & & & & & & $\checkmark$ & & $\checkmark$ & & $\checkmark$ & & & $\mathrm{v}$ & & & & & & & & & & & & \\
\hline (d) The King otherwise had knowledge of the contest & & $\checkmark$ & & & & & $\checkmark$ & & $\checkmark$ & & & $\checkmark$ & & & & & & {$[\sqrt{ }]$} & & & {$[\sqrt{ }]$} & & & & \\
\hline (e) The contest was to take place in the house of a minister [Count Flemming] & & $\checkmark$ & & & & & $\checkmark$ & $\checkmark$ & $\checkmark$ & $\checkmark$ & & $\checkmark$ & $\checkmark$ & $\checkmark$ & & $\checkmark$ & & $\sqrt{2}$ & & $\checkmark$ & $\sqrt{2}$ & & & & $\checkmark$ \\
\hline $\begin{array}{l}\text { 2. Why Marchand had remained in Dresden } \\
\text { (a) The King had offered Marchand a large salary to stay in Dresden }\end{array}$ & & $\checkmark$ & & & & $\checkmark$ & $\checkmark$ & $\checkmark$ & $\checkmark$ & $\checkmark$ & & $\checkmark$ & $\checkmark$ & & & & & & & & & & & & \\
\hline (b) Marchand had otherwise been offered a court position in uresuen & & & & & & & & & & & $\checkmark$ & & & $(\sqrt{ })$ & & & & $\mathrm{a}$ & & & & & & & \\
\hline $\begin{array}{l}\text { 3. Why Bach was in Dresden } \\
\text { (a) Bach was invited to Dresden expressly for the contest }\end{array}$ & & $\checkmark$ & & $\checkmark$ & $\checkmark$ & $\checkmark$ & $\checkmark$ & $\checkmark$ & $\checkmark$ & $\checkmark$ & $\checkmark$ & $\checkmark$ & $\checkmark$ & & & & & $\checkmark$ & & {$[\mathrm{v}]$} & {$[\sqrt{ }]$} & & & & \\
\hline (b) Bach and Marchand were in Dresden at the same time by chance & $\checkmark$ & & $\checkmark$ & & & & & & & & & & & $\checkmark$ & $(\sqrt{ })$ & $\checkmark$ & $(\sqrt{ })$ & & $(\mathrm{v})$ & & & $\checkmark$ & & $(\sqrt{ })$ & \\
\hline (c) It is probable that Bach travelled to Dresden to hear Marchand & & & & & & & & & & & & & & & & & & $\checkmark$ & & $\mathrm{s}$ & $\mathrm{s}$ & & $\checkmark$ & & \\
\hline $\begin{array}{l}\text { 4. Why the contest came about } \\
\text { (a) The presence of two virtuosi in Dresden led to discussions over which was greater }\end{array}$ & & & & & & & & & & & & & & $\checkmark$ & & $\checkmark$ & & & & & & & & & \\
\hline (b) The presence of two virtuosi in Dresden suggested a contest & & & $\checkmark$ & & & & & & & & & & & & & & $\checkmark$ & $\mathrm{v}$ & $\checkmark$ & $(\vee)$ & $\checkmark$ & $(\sqrt{ })$ & $\checkmark$ & & $(\sqrt{ })$ \\
\hline (c) The challenge came from Bach & $\checkmark$ & $\checkmark$ & & & & $\checkmark$ & $\checkmark$ & $\checkmark$ & $\checkmark$ & $\checkmark$ & $\checkmark$ & $\checkmark$ & $\checkmark$ & $\checkmark$ & $\checkmark$ & $\checkmark$ & & $\checkmark$ & & & $\mathrm{a}$ & & & $\mathrm{v}$ & \\
\hline (d) The challenge came from Marchand & & & & $\checkmark$ & $\checkmark$ & & & & & & & & & & & & & & & & & & & & \\
\hline (e) The court musicians sided with Bach and the courtesans with Marchand & & & & & & & & & & & & & & $\checkmark$ & & $\checkmark$ & & & & & & & & & \\
\hline $\begin{array}{l}\text { 5. Who heard whose playing prior to the contest } \\
\text { (a) Bach secretly heard Marchand's playing prior to the contest }\end{array}$ & & $\checkmark$ & & & & $\checkmark$ & $\checkmark$ & $\checkmark$ & $\checkmark$ & $\checkmark$ & $\checkmark$ & $\checkmark$ & & $\checkmark$ & & & & & & $(\checkmark)$ & $(v)$ & & & & \\
\hline (b) Bach openly heard Marchand's playing prior to the contest & & & & & & & & & & & & & $(\sqrt{ })$ & & & & & & & & & & & & \\
\hline $\begin{array}{l}\text { (c) Marchand was presumed to have heard Bach's playing prior to the contest } \\
\end{array}$ & & & & & & & & & & & & & & $\begin{array}{l} \\
\end{array}$ & $\mathrm{a}$ & $\begin{array}{ll} \\
\end{array}$ & & & $\mathrm{a}$ & & & $\mathrm{a}$ & & & \\
\hline $\begin{array}{l}\text { 6. Whether the contest took place } \\
\text { (a) One public performance took place before Marchand's flight }\end{array}$ & & & & & & $\checkmark$ & & & & & $\checkmark$ & $\checkmark$ & $\checkmark$ & & & & & & & & {$[\sqrt{ }]$} & & & & \\
\hline (b) Marchand fled prior to the contest taking place, for reasons not specified & & $\checkmark$ & $\checkmark$ & & & & $\checkmark$ & $\checkmark$ & $\checkmark$ & $\checkmark$ & & $\checkmark$ & & & & & & $\checkmark$ & & & & & $\checkmark$ & & \\
\hline (c) Marchand fled expressly because he doubted he could win & $\checkmark$ & & & & & $\checkmark$ & & & & & $\checkmark$ & & $(\sqrt{ })$ & r & $\checkmark$ & $\checkmark$ & $\checkmark$ & & $\checkmark$ & $\checkmark$ & $(\sqrt{ })$ & $\checkmark$ & & {$[\checkmark]$} & \\
\hline (d) Bach entertained the assembled company alone, in Marchand's absence & & $\checkmark$ & $\mathrm{r}$ & & & & $\checkmark$ & $\checkmark$ & $\mathrm{a}$ & $\begin{array}{c} \\
\end{array}$ & & $\checkmark$ & $\mathrm{s}$ & $\begin{array}{l}\mathrm{r} \\
\end{array}$ & & & & $\mathrm{a}$ & & & $\checkmark$ & & $\mathrm{a}$ & & \\
\hline $\begin{array}{l}\text { 7. The reputational consequences of the episode (for Bach/Germany) } \\
\text { (a) The episode brought honour to Bach, or helped spread his fame nationally }\end{array}$ & $\checkmark$ & $\checkmark$ & & $(v)$ & & & & & & & & & & $\checkmark$ & & $\checkmark$ & $\checkmark$ & & $\checkmark$ & $\checkmark$ & $\checkmark$ & $\checkmark$ & & & $\checkmark$ \\
\hline (b) Bach defended the honour or superiority of the German nation & $\checkmark$ & & & & & & $\checkmark$ & & $\checkmark$ & & & & $\checkmark$ & & & & & $\checkmark$ & & & $\checkmark$ & $\checkmark$ & & & {$[\sqrt{ }]$} \\
\hline (c) Bach explicitly achieved a victory & & & & $\mathrm{e}$ & $\checkmark$ & & & & & & & & & ( & & $\checkmark$ & & $\checkmark$ & & & 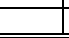 & $\mathrm{g}$ & & & \\
\hline $\begin{array}{l}\text { 8. The intentions of the contest (in terms of nationality and music) } \\
\text { (a) The contest was an attempt to assert German musical superiority }\end{array}$ & & & & & & & & & & & & & & & & & & & & & $\checkmark$ & & & & \\
\hline (b) The contest was intended as a comparison of German vs French art & & & $\checkmark$ & & & & & $\checkmark$ & & $\checkmark$ & & $\checkmark$ & & $\checkmark$ & & & & & & & & & $(\mathrm{V})$ & & \\
\hline Whether Bach received the monetary reward intended for him & & $\checkmark$ & & & & & & $\checkmark$ & & $\checkmark$ & & $\checkmark$ & $\checkmark$ & & & & & & & & & & & & \\
\hline
\end{tabular}




\section{Table 2: Key to Sources for Biographical Accounts of the 1717 Contest between J.S. Bach and Marchand}

\section{Source}

Birnbaum (1739)

Bach and Agricola (1754)

Adlung (1758)

Burney (1773)

Hawkins (1776)

Marpurg (1786)

Gerber (1790)

Forkel (1802)

Choron and Fayolle (1810)

Sainsbury (1825)

Fétis (1835)

Hilgenfeldt (1850)

Bitter (1865)

Spitta (1873)

Grove 1 (1879)

Williams (1900)

Schweitzer (1905)

Schweitzer (1908, 1911)

Parry (1909)

Grove 3 (1927)

Terry (1928)

Grew and Grew (1947)

Geiringer (1966)

Boyd (1983)

Wolff (2000)

\section{Bibliographic details}

J.A. Birnbaum, "Vertheidigung seiner unparteyischen Anmerkungen..." (1739), 981-2

C.P.E. Bach and J.F. Agricola, "Denkmal dreyer verstorbenen Mitglieder..." [Nekrolog] (1754), 163-5

J. Adlung, Anleitung zu der musikalischen Gelahrtheit (1758), 690

C. Burney, The Present State of Music in Germany... (1773), II, 81-2

J. Hawkins, A General History of the Science and Practice of Music (1776), V, 255

F.W. Marpurg, Legende einiger Musikheiligen (1786), 291-3

E.L. Gerber, Historisch-Biographisches Lexicon der Tonkünstler, 1st edn. (1790-2), I, col. 87

J.N. Forkel, Ueber Johann Sebastian Bachs Leben... (1802), 7-8

A.-E. Choron and F.J. Fayolle, Dictionnaire historique des musiciens (1810-11), I, 35-6

J. Sainsbury, A Dictionary of Musicians From the Earliest Times (1825), I, 46-7

F.-J. Fétis, Biographie universelle des musiciens..., 1st edn. (1835-44), II, 10

C.L. Hilgenfeldt, Johann Sebastian Bach's Leben, Wirken und Werke(1850), 23-6

C.H. Bitter, Johann Sebastian Bach (1865), I, 104-7

P. Spitta, Johann Sebastian Bach (1873-80), I, 574-7

G. Grove (ed.), A Dictionary of Music and Musicians..., 1st edn. (1879-90), I, 115 [A. Maczewski]

C.F.A. Williams, Bach (1900), 46-7

A. Schweitzer, J.S. Bach, le Musicien-Poète (1905), I, 134-5, 141-2

A. Schweitzer, J.S. Bach (1908), I, 139-40, 163 (Eng. trans., 1911, I, 153-4, 177-8)

C.H.H. Parry, Johann Sebastian Bach... (1909), 101-2

H.C. Colles (ed.), Grove's Dictionary..., 3rd edn. (1927-8), I, 159 [C.S. Terry]

C.S. Terry, Bach: A Biography (1928), 110-12

E.M. Grew and S. Grew, Bach (1947), 69

K. Geiringer and I. Geiringer, Johann Sebastian Bach... (1966), 40

M. Boyd, Bach (1983), 42

C. Wolff, Johann Sebastian Bach: The Learned Musician (2000), 179-82

\section{Account based on}

?testimony of J.S. Bach (possibly supervised; see above, n. 11)

C.P.E. Bach (co-author)

testimony of J.S. Bach (stated)

?testimony of J.C. Bach (see also above, n. 20)

testimony of J.C. Bach (stated)

testimony of J.S. Bach (stated)

?Nekrolog

Nekrolog; ?additional testimony of W.F. Bach and/or C.P.E. Bach nuanced trans. of Gerber

Forkel (direct trans.)

Nekrolog, Forkel; elements of Marpurg

Marpurg; Nekrolog, Forkel

Marpurg; Nekrolog, Forkel

Birnbaum, Adlung, Nekrolog, (Marpurg) (all stated); Forkel

Spitta (revised and condensed)

Spitta (stated)

Forkel (stated, but greatly summarised)

Forkel (stated); Schweitzer (French version); (elements of Spitta)

Various sources (indicated but not stated)

Schweitzer; Forkel (stated)

Forkel, Birnbaum; Marpurg, Nekrolog, Adlung, (Burney) (all stated) (elements of Spitta and other sources)

(elements of sources including Schweitzer and/or Terry)

Nekrolog; Birnbaum (both stated)

Nekrolog (quoted); Birnbaum (stated) 
individual themes are parenthetically referenced in the following discussion using this system of identification. The method adopted here is consonant with that employed by K.M. Knittel for her detailed analysis of the recurring motifs associated with the archetypal "quest plot" that emerges from collectively reading a set of nineteenth-century self-narratives of visits made to Beethoven by different "pilgrims," as well as being a natural offshoot of my own practices of isolating discernible series of biographical tropes and sub-tropes in my wider research conducted across the life-writing on several different Great Composers. ${ }^{17}$

Nineteenth-century Bach biographies prior to Spitta typically followed the accounts presented by the "Nekrolog" and/or Forkel, which therefore provide a suitable point of departure for the exploration of the mythology at the centre of my study as well as for the exposition of some of its principal themes. Both sources held that Bach had been summoned to Dresden for the specific purpose of standing against Marchand in contest (Table 1, theme 3(a)), the invitation having been extended by the court Kapellmeister, an assimilated Frenchman named Jean-Baptiste Volumier (theme 1(a)). According to this version of the story, Volumier had apparently contrived for Bach secretly to hear Marchand's playing prior to his issuing the challenge by means of a polite letter (theme 5(a)), thereby giving him advance knowledge of the abilities of his opponent. ${ }^{18}$ On the day itself, for some

17 K.M. Knittel, “Pilgrimages to Beethoven: Reminiscences by his Contemporaries,” Music E Letters 84/1 (2003): 19-54. Wiley, Re-writing Composers' Lives, Vol. 1, 180-312 and Vol. 2, 129-204.

18 If such a letter were ever written, it has not survived; see Bach-Dokumente edited by Neumann and Schulze, Vol. 1 (1963), 26-7. Forkel mistakenly contradicted himself, later in his biography, in suggesting that Bach was "not the challenger in this case, but the challenged." Forkel, “On Johann Sebastian Bach's Life, Genius, and Works," 459. 
unspecified reason, Marchand was said to have fled Dresden by express coach (theme 6(b)); Bach was therefore left to entertain the assembled crowd on his own, and he reportedly obliged (theme $6(\mathrm{~d})$ ), meeting with great success.

Differing authorial agendas are evident from the earliest accounts. For instance, Birnbaum's appeared within the broader context of his controversial series of printed exchanges with J.A. Scheibe (originating in the journal that the latter had founded in 1737, Der Critische Musikus), staunchly defending Bach against Scheibe's criticisms of his compositional style as well as the suggestion that Handel was the greater keyboardist. ${ }^{19}$ One national variant, indeed, is largely consigned to the eighteenth century: the retellings by Burney and Hawkins seemed to exist in parallel with those by the early German writers, as noted, and have subsequently been largely overlooked even by biographers of the present day. ${ }^{20}$ While these two accounts differ from all the rest, they remaining strikingly consonant with one another, which represents something of a historical irony given that the two authors have often been traditionally positioned as rivals on the basis of their publications of

20 Breig connected these sources to two precursory writings by Marpurg (which appear to have had little bearing on the account given in his later Legende einiger Musikheiligen), Traité de la fugue et du contrepoint (Berlin: Haude et Spener, 1756) and particularly Historisch-kritische Beyträge zur Aufnahme der Musik, 5 Vols. (Berlin: Schuitzens, 1754-60). See Breig, “Bach und Marchand in Dresden," 9, 11. As we shall presently see, Burney's and Hawkins's narratives possessed one highly distinctive element in common with Marpurg's final account, in that all indicated that an event of some nature featuring Bach and Marchand as performers did occur; in addition, both Marpurg's retelling in his Historisch-kritische Beyträge (Vol. 1, 450-1, at 451) and Burney's in The Present State of Music in Germany, The Netherlands, and United Provinces (Vol. 2, 81-2, at 82) drew comparison between Marchand's defeat by Bach and Pompey's by Caesar. One later biographical text that, exceptionally, demonstrated explicit awareness of Burney's account was Terry, Bach, 112. 
competing histories of music, ${ }^{21}$ adding weight to the supposition that each relied on the common source of Johann Christian Bach for their information. As shown in Table 1, both Burney and Hawkins held that the contest was initiated by the King of Poland, in his capacity as Elector of Saxony (theme 1(b)), rather than by Volumier, and that the challenge came directly from Marchand (theme 4(d)), whereas other eighteenth-century and later accounts overwhelmingly considered Bach, if anybody, to have been the challenger (theme $4(\mathrm{c})) .{ }^{22}$ The possibility of the King's involvement in proceedings has essentially been discounted following archival research conducted by Spitta, which found no documentary record of Bach's having performed before him; in any case, as Spitta also noted, had the King himself played a role in proceedings then the event would doubtless have been held at the Dresden court, rather than at the house of a minister (theme 1(e)), identified by Forkel as Count Flemming, who subsequently became one of Bach's foremost supporters at Leipzig. ${ }^{23}$ Most significant, however, is the manner in which Burney and Hawkins each alluded to the "victory" Bach attained over Marchand (theme 7(c)), implying that the contest did indeed take place, rather than that Bach won only by default if at all. ${ }^{24}$ An anonymous statement of 1788 latterly attributed to C.P.E. Bach (and before

21 Hawkins, A General History of the Science and Practice of Music (cited above, n. 14); Charles Burney, A General History of Music, from the Earliest Ages to the Present Period, 4 Vols. (London: Author, 1776-89).

22 The report given by Forkel conflicts in this respect with a statement made later in the same biography identifying Bach as "not the challenger in this case, but the challenged". Forkel, "On Johann Sebastian Bach's Life, Genius, and Works," 459; cf. ibid., 428.

23 See Spitta, Johann Sebastian Bach, translated by Bell and Maitland, Vol. 1, 646-7 and Forkel, “On Johann Sebastian Bach's Life, Genius, and Works," 428.

24 Burney, The Present State of Music in Germany, The Netherlands, and United Provinces, Vol. 2, 81-2; Hawkins, A General History of the Science and Practice of Music, Vol. 2, 853. 
him to A.F.C. Kollmann) explicitly stated that Marchand himself had "retired modestly without victory" back to France, ${ }^{25}$ while both the "Nekrolog" and Forkel suggested that neither was Bach considered to have triumphed over his competitor, since he was not awarded the money that had been promised to the victor of the contest (theme 9). Over a century later, these accounts were themselves called into question by C.S. Terry, one of the foremost authorities on Bach of his day, who contended that "The statement made by the "Nekrolog" and Forkel, that Bach was deprived of a substantial honorarium by the dishonesty of a Court official, is probably aprocryphal". ${ }^{26}$

In this respect, it is a pity that Spitta's endeavours to unravel the web of discrepancies that had enveloped eighteenth-century reports of the tale did not encompass the accounts by either Burney or Hawkins, as it might have effected a rehabilitation of the episode's English variant within its wider emergent mythology. ${ }^{27}$ Yet Spitta brought about the previously mentioned turning-point in the development of the myth precisely through undertaking to consider more fully the early sources and the discrepancies between them, rather than merely basing his own retelling on - and thereby accepting at face value - the one-sided narratives that he had inherited via the mediation of previous life-writing, which (as scrutiny of Table 1 reveals) had generally been indebted to the dominating accounts of the

25 "A Comparison of Bach and Handel [by Carl Philipp Emanuel Bach?]" (cited above, n. 9), 408.

26 Terry, Bach, 112, n. 5. Spitta's view was that this was a gloss originating in the Bach family; Spitta, Johann Sebastian Bach, translated by Bell and Maitland, Vol. 1, 647.

27 Spitta's retelling of the story within his own biographical narrative is to be found in Johann Sebastian Bach, translated by Bell and Maitland, Vol. 1, 583-5 (cf. Vol. 1, 574-7 of the German original). See also his extensive supplementary analysis of the episode discussed above, n. 15. 
"Nekrolog" and Forkel. As I have elsewhere argued, Spitta's landmark text is particularly significant for having inadvertently activated fresh trajectories along which distinct biographical myths associated with Bach were subsequently diverted, and not merely in respect of this one isolated example. Another concerns Spitta's attempt to correct Forkel's error in stating (apparently owing to a misreading of the "Nekrolog") that Bach's fabled journey on foot to Lübeck to hear Buxtehude perform in 1705 had resulted in his listening to the older organist's playing only secretly, following which a number of major biographers were led to speculate as to whether Bach had not only made himself known to Buxtehude, but also taken lessons from him. ${ }^{28}$

Spitta's more informed version of events of the competition between Bach and Marchand, while nonetheless acknowledging Volumier's presence in Dresden, fell short of ascribing to him the role of having contrived to bring about the occasion. Instead, Spitta reintroduced the notion originating in Birnbaum's and Adlung's accounts that Bach had been in Dresden "quite by chance" (theme $3(\mathrm{~b})$ ). ${ }^{29} \mathrm{He}$ explicitly privileged the accounts by these two authors partly because of their strong level of consonance with one another, and because he held that Birnbaum's, given that the author's public defence of Bach against Scheibe's criticisms had been written

28 Spitta, Johann Sebastian Bach, translated by Bell and Maitland, Vol. 1, 262-3 and n. 106. For further elaboration of this point, see Wiley, Re-writing Composers' Lives, Vol. 1, 46-7.

29 Spitta, Johann Sebastian Bach, translated by Bell and Maitland, Vol. 1, 583; the original reads "nun zufällig" (Vol. 1, 575 in the German edition). While discussion throughout this chapter quotes from standard translations of texts (where they exist) for the reader's convenience, I have nonetheless satisfied myself that they are sufficiently representative of the associated account as it appears in the original language to support the interpretations that I have drawn, separately quoting the original text in those instances where it offers additional nuances. 
under the composer's direct supervision, was therefore the most reliable and convincing of the divergent eighteenth-century sources. ${ }^{30}$ However, in his distancing of the versions offered by both the "Nekrolog" and Marpurg on the basis of such piecemeal detail, Spitta may have inadvertently permitted the proverbial pendulum to swing too far in the opposite direction. For instance, his revisionist narrative included the claim that Marchand had departed so suddenly - and secretly because he knew that he would not win the competition, speculating that "Marchand must have heard him somewhere or other, and have convinced himself that the German musician was infinitely his superior" (theme 5(c)). ${ }^{31}$ While this suggestion had been implicit in earlier accounts, Spitta's could state it overtly because he, unlike many authors before him, had identified that Marchand had foreknowledge of his opponent.

The position advanced by Spitta was, of course, a reversal of previous versions of the story, in which it had been Bach who had heard Marchand prior to the contest either secretly (theme 5(a)) or, in Marpurg's version, openly (theme 5(b)). Whereas Spitta's account did concede that Bach had also heard Marchand in secret (a crucial piece of information omitted from some of the retellings that followed in its wake, as Table 1 identifies), it held that only at this point in the story was Bach prompted by unnamed friends to challenge Marchand on home territory (in continuation of theme 4(c)). That removed an important element of premeditation from the episode in that Bach was no longer seen to have been in town for the sole purpose of participating in a competition, which had been a premise common to

\footnotetext{
30 Spitta, Johann Sebastian Bach, translated by Bell and Maitland, Vol. 1, 644-5.

31 Spitta, Johann Sebastian Bach, translated by Bell and Maitland, Vol. 1, 585.
} 
many of the eighteenth-century sources (theme 3(a)). He was thereby portrayed as the more confident of the two performers, throwing down the gauntlet spontaneously and without having prepared himself in advance for a contest, rather than travelling to the town purposefully as the brave challenger to the local hero. Establishing this matter must have been particularly important to Bach biography given the absence of the emergence of a clear winner (at least, according to the majority of accounts) since, as mentioned, any victory Bach had gained over Marchand was therefore essentially passive.

In the course of nineteenth-century biographical retellings, the tale of the contest evolved to transcend the simple rivalry between two individuals, becoming appropriated more widely as presumed evidence of the hegemony of German music as against perceived French philistinism. Spitta himself speculated that Marchand doubtless judged his competitor to be the better player not only on the organ but the clavier as well, remarking that the latter instrument might have been expected to favour Marchand since, "according to the general opinion of the time, the French school had the advantage and preference". In so doing, he presented Bach's supposed triumph over Marchand as having taken place "on his own special ground," both literally (in Dresden) and artistically. ${ }^{32}$ However, the role played by Volumier - who, in many of the accounts up until the mid-nineteenth century, was credited with having invited Bach to take part in the contest (theme 1(a)) - ran contrary to this interpretation, and hence represented one of the principal difficulties that Spitta encountered with the story's national resonances. Volumier (Woulmyer), 
who was born in Spain with Flemish roots and educated in France, would have had little to gain from effectively demonstrating German musical superiority by summoning a challenger believed capable of defeating Marchand. Given his Latin descent, his only possible motivations might have been on a more personal level, to cut the conceited Marchand down to size or, as Fétis had ventured some years earlier in his monumental Biographie universelle des musiciens, possibly acting either out of a desire to remove Marchand from his position at court or jealousy at the favour that he was increasingly eliciting (which might, had circumstances been different, have resulted in a permanent appointment). ${ }^{33}$ This tension had, indeed, been implicitly addressed in accounts as early as Forkel's, which went only so far as to suggest that Volumier's aim had been "to show, in a sensible and striking manner, the difference between the French and German art," but not that he had intended to bring about a comparison between them in a bid to demonstrate the music of one country to be better than the other. ${ }^{34}$

Indeed, indications that the episode provided an apparent illustration of the pre-eminence of German keyboard-playing are traceable all the way back to the earliest sources, being particularly apparent from Adlung's account of 1758. Both the "Nekrolog" and Forkel offered a narrative that seemed to promote Bach's German school above Marchand's French one, Forkel (and, somewhat later, Spitta) even

33 These suggestions are made in the articles on Marchand and Bach, respectively, of Fétis's dictionary, which (as I shall later discuss) themselves offer conflicting accounts and are based on different sources. F[rançois]J[oseph] Fétis, “Marchand (Louis)” and “Bach (Jean-Sébastien)," in Biographie universelle des musiciens et bibliographie générale de la musique, 8 Vols. (Brussels, Paris: Firmin Didot, 1835-44), Vol. 6, 264-5, at 265 and Vol. 2, 9-19, at 10.

34 Forkel, “On Johann Sebastian Bach's Life, Genius, and Works," 428. 
broadening his line of enquiry to encompass François Couperin, the composer with the strongest claim to being Bach's French Baroque counterpart as well as the greatest representative of a comparable national dynasty in music. While Forkel had high praise for Marchand's "very fine and elegant style" in performance, his indication that "Marchand's [...] ideas were empty and feeble, almost in the manner of Couperin, at least as may be judged by his compositions" left the reader in no doubt as to which out of the French and German schools of music he considered superior. ${ }^{35}$ So strongly was Forkel's point expressed that Terry, in his own translation of the biography (1920), published in the centenary year of the appearance of its first complete English-language version, was keen to observe that "Forkel's judgment upon [Couperin's] art is not supported by modern criticism". ${ }^{36}$

The trope of Bach's defending his nation's honour as well as his own, meanwhile, was already explicitly stated in the earliest account, by Birnbaum, published in 1739 (theme 7(b)). ${ }^{37}$ It was perpetuated thereafter in Gerber's (1790-2) and Choron and Fayolle's (1810-11) milestone biographical dictionaries, the subtle shift of phraseology from "die Ehre seiner Nazion" (the honour of his nation) in the former to "la supériorite de sa nation" (the superiority of his nation) in the latter being particularly revealing in this respect since their accounts were demonstrably

35 Forkel, “On Johann Sebastian Bach's Life, Genius, and Works,” 427. Spitta's own assessment seemed to echo Forkel's through the comparison to Couperin: “Marchand's works [...] are not inferior to Couperin's clavier works in variety and grace [...] and are besides, like everything French, excessively difficult to play." Spitta, Johann Sebastian Bach, translated by Bell and Maitland, Vol. 1, 585.

36 Forkel, Johann Sebastian Bach: His Life, Art, and Work translated by Charles Sanford Terry (London: Constable, 1920), 18, n. 3. The earliest English translation of this text, attributed to Stephenson, was as Life of Bach: With a Critical View of his Compositions (London: Boosey, 1820).

37 On this point see Wolff, Johann Sebastian Bach, 179. 
based on one another, and given that neither text shared Birnbaum's previously noted agenda of defending Bach against the various charges that had been levelled against him by Scheibe. ${ }^{38}$ Some generations later, this was another aspect of the story broadened by Spitta, who acknowledged that the dichotomy between the two nationalities extended to the setting of the Dresden court itself, where opinion was reportedly divided between its members, who favoured French music, and its musicians, who were predominantly German, and therefore more inclined to side with Bach as an exponent of their own artistic traditions (theme 4(e)).

This whole interpretation of the episode was understandably resisted in French-language biography. Fétis - whose musical writings, while opinionated and not always factually reliable, were nonetheless hugely influential in nineteenth-century Franco-Belgian circles - overtly criticized “Les biographes allemands" (although he never specified exactly which German biographers he had in mind) in his retelling of the story in the Biographie universelle des musiciens (183544). His chief complaint was that such writers had omitted to acknowledge that even if the quality of Marchand's compositions left something to be desired, he might nonetheless have excelled in performance. ${ }^{39}$ At face value, it could hardly have been

38 Ernst Ludwig Gerber, "Bach (Joh. Sebastian)," in Historisch-Biographisches Lexicon der Tonkünstler, 2 Vols. ([Leipzig: Breitkopf], 1790-2), Vol. 1, cols. 86-92, at col. 87. Al[exandre-Etienne] Choron and F[rançois Joseph] Fayolle, "Bach (Jean-Sébastien)," in Dictionnaire historique des musiciens: Artistes et amateurs, morts ou vivans, 2 Vols. (Paris: Valade [et] Lenormant, 1810-11), Vol. 1, 35-8, at 35.

39 'Il se peut que Marchand ait eu ce qu'on appelle une exécution brillante, mais ses compositions sont misérables. On n'y trouve que des idées communes, une harmonie faible, lâche, incorrecte; son ignorance du style fugué est complète." Fétis, “Bach (Jean-Sébastien)," Vol. 2, 10. Similar sentiments were conveyed in Fétis‘s parallel article on the Frenchman: “Marchand pouvait avoir une exécution brillante, mais ses idées 
otherwise, since the success of the episode as biographical anecdote is predicated on there having been an element of uncertainty as to whether Marchand was a greater performer even than Bach. Pioneering French musicologist André Pirro was to take the defence of Marchand further still in his Bach biography of 1906, his observation that the German composer had set Marchand's music for his pupils to study serving to indicate that Bach must therefore have regarded his rival highly. ${ }^{40}$ Pirro, who had elsewhere written on Marchand and was familiar with his works, ${ }^{41}$ quoted the episode wholesale from the "Nekrolog" rather than attempt to retell it newly himself, doubtless to preserve his own authorial distance from resonances of the politics of nationality that would have sat uneasily with his Francophonic readership. There was, then, a certain tendency perceptible amongst Latin authors towards damage limitation and pleas of mitigation in respect of those aspects of the story that were so demeaning to a French musician, even one whose place in music history - as viewed from Pirro's time, as well as Fétis's - was comparatively minor.

sont triviales, son harmonie pauvre et incorrecte; il n'avait d'ailleurs que des notions fort inexactes du style fugué, sans lequel on ne saurait produire de grands effets sur l'orgue”. Fétis, “Marchand (Louis)," Vol. 6, 265.

40 André Pirro, J.-S. Bach, "Les Maîtres de la Musique” series (Paris: Alcan, 1906), 50-2, at 52. Spitta had previously noted that Bach had known of Marchand's works for some time prior to their meeting, but did not pursue the point to the same lengths as Pirro. Spitta, Johann Sebastian Bach, translated by Bell and Maitland, Vol. 1, 585 and n. 306.

41 Pirro had previously written on Marchand in his biographical introductions to the composer's works appearing in the Archives des Maîtres de l'Orgue des XVI $X V I I^{e}$ et XVIII ${ }^{e}$ Siècles edited by Alexandre Guilmant and André Pirro, 10 Vols. (Paris: Durand, 1901-10), Vol. 3 (53-8; see 56-7 on Marchand's contest with Bach) and Vol. 5 (197-201); and he was the author of the article “Louis Marchand (1669-1732)," La Tribune de SaintGervais 6/1 (January 1900): 1-8 as well as the lengthier "Louis Marchand," Sammelbände der Internationalen Musik-Gesellschaft 6/1 (October-December 1904): 136-59. 
We have it on Terry's authority ${ }^{42}$ that the version of the story favoured in France was that originating in the one major eighteenth-century source that has not yet been extensively discussed, by Marpurg, published in 1786. According to his report, one concert had taken place (theme 6(a)), during which Marchand and Bach had taken turns at the keyboard - suggesting that the two performers had stood up satisfactorily against one another - before the competition was proposed and Marchand took flight. Marpurg certainly held Bach in high esteem: he had been invited to contribute the preface to the 1752 edition of Die Kunst der Fuge, and made generous reference to Bach and his works in his historically important treatise, Abhandlung von der Fuge (1753-4). ${ }^{43}$ But his account was more sympathetic to Marchand as well, and it was in this form that the episode found its way into lifewriting on the French composer, in those instances where it even appeared. Being substantially less developed than corresponding discourses on Bach given their relative historical standing, Marchand was inevitably accorded much less space in collected biographies and dictionaries. Whereas both Gerber, and Choron and Fayolle, nonetheless found scope to mention the episode in their entries on the French composer (in each case clearly following Marpurg's version of events, explicitly cited by the former as his source), the same cannot be said for Gerber's greatly expanded second edition, nor for Sainsbury's English-language dictionary,

43 [Friedrich Wilhelm] Marpurg, “Vorbericht,” in Johann Sebastian Bach, Die Kunst der Fuge ([Leipzig], 1752), translated as "Preface to the 1752 edition [of The Art of Fugue]," in The New Bach Reader edited by David, Mendel, and Wolff, 375-7. [Friedrich Wilhelm Marpurg], Abhandlung von der Fuge nach den Grundsätzen und Exempeln der besten deutschen und ausländischen Meister entworfen, 2 Vols. (Berlin: Haude und Spener, 1753-4). 
which was partly based on these same texts. ${ }^{44}$ Hence several major publications either did not reference the anecdote at all in connection with Marchand's life story, or alluded to it only in passing, or even seemed to respond to it implicitly without addressing it directly. One of the most pronounced examples of the latter phenomenon is yielded by Titon du Tillet's Le Parnasse françois (1732), a major source on Marchand's biography, which omitted mention of the episode while nonetheless taking pains to account for the composer's unanticipated departure from Dresden (i.e. theme 6(b)) by claiming that his sudden return to Paris was due to his having grown weary of being no longer able to see the city, where he had been active for over 20 years prior to embarking on his tour of Germany ${ }^{45}$ - an explanatory strategy likely put forward mindful that readers might already be acquainted with the very story for which Marchand is primarily remembered by history.

Doubtless the intervention of the politics of nationality was itself a major factor driving this trend, given that life-writing on Marchand was primarily (although not exclusively) French, coupled to Marpurg's report being at variance with all previous eighteenth-century German sources as well as with subsequent biographical discourses on Bach. The conflict between divergent narratives was

44 Gerber, "Marchand (Jean Louis)," in Historisch-biographisches Lexikon der Tonkünstler, 2 Vols. ([Leipzig: Breitkopf], 1790-2), Vol. 1, cols. 870-2, at col. 870-1. Choron and Fayolle, “Marchand (Jean-Louis)," in Dictionnaire historique des musiciens, Vol. 2, 12-13, at 12. Ernst Ludwig Gerber, “Marchand (Iean Louis)," in Neues historisch-biographisches Lexikon der Tonkünstler, 2nd edn. (of text cited above, n. 38), 4 Vols. ([Leipzig: Kühnel], 1812-14), Vol. 3, col. 316. [John Sainsbury], “Marchand (Jean Louis)," in A Dictionary of Musicians From the Earliest Times, 2 Vols. (London: Sainsbury, 1825, 2/1827), Vol. 2, 110-1. Sainsbury's dictionary did, however, recount the story in the context of the entry on Bach; “Bach (John Sebastian)," Vol. 1, 44-9, at 46-7. See further, below, n. 46 .

45 "Marchand s'ennuya bientôt de ne plus voir Paris; il y revint". [Evrard] Titon du Tillet, "Jean-Louis Marchand," Le Parnasse françois (Paris: Coignard, 1732), 658-60, at 659. 
arguably most pronounced when the anecdote appeared in the major dictionaries of the long nineteenth century, including those of Gerber (in its first edition), Choron and Fayolle, Fétis, and Grove: in each, the account presented in their respective articles on Marchand (all based on Marpurg's Legende einiger Musikheiligen) co-existed alongside a different variant of the same story retold elsewhere in the same publication in connection with Bach. ${ }^{46}$ In the case of Grove's Dictionary, this curious juxtaposition of contradictory stories persisted up to and including H.C. Colles's fourth edition (1940), the entry on Marchand having received a revealing codicil as of the third (1927) whereby the figure of Bach was given greater prominence through the mention of one of Marchand's fugue themes being used in Bach's Brandenburg Concertos, thereby establishing Marchand's compositional credentials and offsetting the more negative undertones of the episode itself. ${ }^{47}$ Nor was Marpurg's version exclusive to Marchand biography even prior to Spitta's detailed evaluation of the eighteenth-century sources: in the preceding decades, Marpurg's variant had already found its way into life-writing on Bach through the

46 Gerber, Historisch-biographisches Lexikon der Tonkünstler, Choron and Fayolle, Dictionnaire historique des musiciens, and Fétis, Biographie universelle des musiciens (citations of articles on Bach and Marchand above, nn. 38, 44, and 33). A. M[aczewski], "Bach, Johann Sebastian," and J.A. F[uller] M[aitland], "Marchand, Louis," in A Dictionary of Music and Musicians edited by Grove (cited above, n. 3), Vol. 1, 114-18, at 115 and Vol. 2, 213, respectively. The first edition of Gerber's publication was itself deeply indebted to the endeavours of Johann Gottfried Walther in connection with his milestone Musicalisches Lexicon oder Musicalische Bibliothec (Leipzig: Deer, 1732).

47 [J.A. Fuller] M[aitland], rev. M.L. P[ereyra], “Marchand, Louis," in Grove's Dictionary of Music and Musicians edited by H.C. Colles, 3rd edn., 5 Vols. (London: Macmillan, 1927-8; 4th edn., with Supplementary Volume, 1940), Vol. 3, 317. A conflicting version of the story, more in keeping with that familiar to Bach biography of the time, was recounted elsewhere in the same publication, in C.S. Terry's entry on the composer newly written for this edition of the dictionary. C.S. T[erry], "Johann Sebastian Bach," in Grove's Dictionary of Music and Musicians edited by Colles, 3rd edn., Vol. 1, 155-71, at 159. 
major biographies of German writers C.L. Hilgenfeldt (1850) and C.H. Bitter (1865), the latter entering into the English language through an abridged translation (1873). ${ }^{48}$

Albert Schweitzer's treatment of this episode was even more telling, given the unique national positioning of his celebrated Bach biography of the earliest years of the twentieth century. Schweitzer, an Alsatian who lived at a time during which the region had oscillated between French and German control, originally published his text in French in 1905; it was subsequently enlarged for the German-language edition of 1908, which was itself translated into English by Ernest Newman three years later. ${ }^{49}$ In the expanded versions, Schweitzer adopted a distinctive approach to the handling of the question of nationality in connection with this story:

\begin{abstract}
After his victory over Marchand in 1717 [Bach] was one of the celebrities of the fatherland. The German musicians were proud to be able to oppose a master of their own race to the French and Italian virtuosi. Let German musicians affect Italian ways if they would, in order to win a cheap renown, let the very existence of a German art be denied; the fact remained that there was such a thing, and that it had publicly triumphed over the other. ${ }^{50}$
\end{abstract}

48 C.L. Hilgenfeldt, Johann Sebastian Bach's Leben, Wirken und Werke (Leipzig: Hofmeister, 1850), 23-6. C.H. Bitter, Johann Sebastian Bach, 2 Vols. (Berlin: Schneider, 1865), Vol. 1, 104-7, abridged translation as The Life of J. Sebastian Bach translated by Janet E. Kay-Shuttleworth (London: Houlston, [1873]), 24-6.

49 Albert Schweitzer, J.S. Bach, le Musicien-Poète, 2 Vols. (Leipzig: Breitkopf \& Härtel, 1905); expanded German translation by the author as J.S. Bach, 2 Vols. (Leipzig: Breitkopf \& Härtel, 1908); English translation by Ernest Newman (Leipzig: Breitkopf \& Härtel, 1911).

50 Schweitzer, J.S. Bach (1911) translated by Newman, Vol. 1, 177-8, italics added. See below, n. 52, for discussion of its German-language counterpart. As I shall momentarily discuss (see n. 56), the retelling of the anecdote itself appears in Vol. 1, 153-4, and the quotation above represents more of an afterthought offered some pages later. 
Schweitzer's biography shifted the episode's focus so as to emphasize Germany's musical opposition to Italy rather than to France, his final say on the matter somewhat awkwardly introducing mention of Italian music and musicians - given that its narrative context was that of a proposed contest with a Frenchman - such that the reader loses sight of the French altogether by the end. In so doing, he effectively recast the opposition of nationalities it originally embodied (notwithstanding that the notion that Marchand had found no comparable rival during his time in both France and Italy was present in retellings as early as Burney's and Hawkins' $\mathrm{s}^{51}$ ), a move surely motivated at least in part by his desire to downplay conflicts closer to home through locating the tale more explicitly within the wider national tensions of which it is emblematic.

While the English version of this passage is essentially a direct translation of the German, 52 it may come as little surprise that the parallel account in Schweitzer's French-language biography is markedly different. There, the anecdote itself was given much shorter shrift, less than half the length of its counterparts in either the

51 Burney reported that Marchand had "vanquished all the organ players of France and Italy," and Hawkins that he had "shewn himself superior to the best organists of France and Italy". Burney, The Present State of Music in Germany, The Netherlands, and United Provinces, Vol. 2, 81; Hawkins, A General History of the Science and Practice of Music, Vol. 2, 853.

52 Cf. Schweitzer, J.S. Bach (1908), Vol. 1, 163. Although the original German text used the formulation "französischen und welschen Virtuosen," in this context "welschen" is clearly intended to refer to the virtuosi of Romance-speaking countries, and specifically to Italians, whom Schweitzer explicitly mentioned in the next sentence of the German-language version. Newman's use of the word "Italian" in his translation is therefore justifiably in keeping with the sense of the original. Some decades previously, Bitter had briefly raised the issue of Italian musicians in connection with this story, noting of Marchand that "In his travels in Italy he had really found no one to rival him;" Bitter, The Life of J. Sebastian Bach translated by KayShuttleworth, 25. 
German or English editions, as if to skip over it as quickly as possible, "en deux mots," to use the author's own words,;3 and it is presented as an illustration of Bach's modesty, upon which Schweitzer's narrative repeatedly insisted, as much as anything else. ${ }^{54}$ That said, echoes of Schweitzer's postscript to his account, quoted above, are nonetheless to be found in his earlier text as well: he alluded to Bach's having experienced the jealousy of the French and Italian virtuosi who were said to have occupied the "meilleures places" (best posts) available in Europe at the time, as well as lamenting the relative paucity of German national heroes, of which he identified only Luther, and subsequently Kant, in addition to Bach. ${ }^{55}$ Moreover, whereas this ancillary discussion appeared many pages removed from the main narrative of the tale in Schweitzer's German and English biographies, ${ }^{56}$ in the French original it followed on more closely, yielding a stronger connection between them.

Although Schweitzer's retelling repeatedly cited Forkel as its source (at least, in the German and English versions), at the same time it contained echoes of Spitta's reconfiguration of the myth. In the course of his own discussion of this episode,

53 Schweitzer, J.S. Bach, le Musicien-Poète, Vol. 1, 134-5, at 135.

54 In life-writing on the composer, the trope of Bach as modest extends all the way back to Forkel's biography, in which it was prominent in the opening of the chapter on the composer's character, which included as evidence this very episode as well as the comment that Bach reportedly "never spoke voluntarily" of it, as mentioned (see above, n. 9). Forkel, “On Johann Sebastian Bach’s Life, Genius, and Works,” 459-62, at 459. Bach's modesty therefore stands in stark contrast to the traditional portrayal of Marchand as proud or arrogant in connection with this same story; the "Nekrolog," for instance, described Marchand as “hochmüthigen” ("haughty”). Bach-Dokumente edited by Neumann and Schulze, Vol. 3, 83; “The World-Famous Organist, Mr. Johann Sebastian Bach," 301.

55 Schweitzer, J.S. Bach, le Musicien-Poète, Vol. 1, 141-2, at 141.

56 Schweitzer's account of the episode itself is to be found in J.S. Bach (1908), Vol. 1, 139-40 and J.S. Bach (1911) translated by Newman, Vol. 1, 153-4. 
Spitta had stated his self-conscious awareness of his position in relation to the agencies of cultural myth-making whose fruits he had inherited, writing that "by analysing [divergent accounts] duly we can plainly detect the process by which a historical myth is gradually developed". ${ }^{57}$ However, in attempting to provide a more rounded picture of the episode, and despite-or precisely because of - his having knowingly intervened in the mythologization to which it had historically been subjected, Spitta himself became unwittingly implicated within it, setting the myth along new paths subsequently pursued at the hands of Schweitzer and others. Accounts in the major English-language biographies of Bach of the early twentieth century likewise extended elements that had been introduced by Spitta, such as the idea that their subject may have travelled to Dresden for reasons other than the competition with Marchand (theme 3(b)). For instance, Terry's volume (1928) suggested that the contest had probably come about as a natural consequence of the presence of two distinguished performers in the same town (theme 4(b)) rather than being the very reason for their coming together, a notion that Spitta had essentially, and doubtless unintentionally, put to an end. Instead, Terry advanced the possibility, previously mooted by Schweitzer, that it was likely that Bach had visited Dresden expressly to hear Marchand perform, owing to "his inveterate inclination to listen to other masters of his instrument" (theme 3(c)). ${ }^{58}$ While Terry was not the first major author to have built upon Spitta's revisionism in proposing different versions of events, then, it is particularly significant that his retelling was clearly indebted to Spitta's account rather than to Forkel's given that Terry had, as noted, published his

57 Spitta, Johann Sebastian Bach, translated by Bell and Maitland, Vol. 1, 646.

58 Terry, Bach, 111. Cf. Schweitzer, J.S. Bach (1911) translated by Newman, Vol. 1, 153. 
own English translation of Forkel's biography just a few years earlier. In a similar vein, Spitta's conjecture that Marchand had heard Bach before the contest, and that "With certain prescience of defeat he had abandoned the field," was apparently so quickly adopted within twentieth-century life-writing on Bach that Hubert Parry's biography (1909) claimed it had "met with general endorsement" - without mentioning that any such ratification could logically only have been comparatively recent. 59

As biographical anecdote, the episode appears to have been viewed with much suspicion by the latter half of the twentieth century, doubtless owing to the advent of more exacting scholarly approaches towards life-writing coupled to widespread knowledge of the substantial discrepancies between the earliest sources. ${ }^{60}$ The articles on both Bach and Marchand for the first edition of Die Musik in Geschichte und Gegenwart raised it only in passing, each explicitly alluding to the extent of the deviations between historical reports. ${ }^{61}$ Wilfrid Mellers's article on the latter for Eric Blom's fifth edition of Grove's Dictionary (1954) dismissed it outright as "no more than suppositious. We do not know that there was not some adequate reason for [Marchand's] having to leave Dresden at this time. He hardly seems to have been a man likely to feel diffidence about his talents, even when opposed to the

59 Spitta, Johann Sebastian Bach, translated by Bell and Maitland, Vol. 1, 584. C. Hubert H. Parry, Johann Sebastian Bach: The Story of the Development of a Great Personality (New York: Putnam, 1909), 102.

60 On the emergence of the so-called "scholarly biography" within literature on music, see further, my “Biography and Life-Writing” (cited above, n. 4).

61 Friedrich Blume, “Bach, Johann Sebastian,” and Félix Raugel and Friedrich Wilhelm Riedel, “Marchand, Louis," in Die Musik in Geschichte und Gegenwart edited by Friedrich Blume, 17 Vols. (Kassel: Bärenreiter, 1949-86), Vol. 1 (1949-51), cols. 962-1047, at col. 975 and Vol. 8 (1960), cols. 1620-1, at col. 1621, respectively. 
greatest." 62 In adopting such a stance, Mellers simultaneously offered an implicit rejoinder to the long-standing biographical trope of his subject's pride before a fall. ${ }^{63}$ Werner Neumann's Bach and his world (1969) merely quoted the account as it appeared in the "Nekrolog" (holding it to be "perhaps the most authentic" of the “many legends about this meeting and countless versions [...] describing Bach's 'bloodless' victory over his rival”), as did Werner Felix's Johann Sebastian Bach (1985); and the story is conspicuous by its total absence from Denis Arnold's book on the composer (1984). ${ }^{64}$

Of the major biographies that have recently appeared, other than Wolff's, only Piero Buscaroli's Italian-language Bach (1985) has addressed the episode at any length (principally referencing Birnbaum and Marpurg), and even then, within the context of a volume well over one thousand pages long. ${ }^{65}$ Alberto Basso (1979-83) shunned the anecdote as a matter of legend, detracting from historical truth; 66 Martin Geck (2000) cited it, at the outset of his German-language biography, as an example of a well-known story that nonetheless continues to raise questions about

62 W[ilfrid] H. M[ellers], "MARCHAND, Louis," in Grove's Dictionary of Music and Musicians edited by Eric Blom, 5th edn., 9 Vols. (London: Macmillan, 1954; Supplementary Volume, 1961), Vol. 5, 568-9, at 568.

63 See the discussion above, n. 54 .

64 Werner Neumann, Bach and his world translated by Stefan de Haan (London: Thames and Hudson, 1961, rev./1969), 45 (the "Nekrolog" is quoted on pp. 45-7). Werner Felix, Johann Sebastian Bach (London: Orbis, 1985), 35-6. Denis Arnold, Bach (Oxford: Oxford University Press, 1984).

65 Piero Buscaroli, Bach (Milano: Mondadori, 1985, 2/1988), 473-6.

66 “L'aneddoto [...] è materia di leggenda piú che di storia. [...] Ma lo stesso episodio sottrae alla storia una parte di verità". Alberto Basso, Frau Musika: La vita e le opere di J.S. Bach, 2 Vols. (Torino: EDT/Musica, 1979-83), Vol. $1,390$. 
the limitations of received knowledge about Bach. ${ }^{67}$ While many of the tendencies discussed above seem now to have been largely brought to a halt in mainstream lifewriting on the composer, however, vestiges of the continuing indebtedness to the mythology that has developed historically may still be located even in the most recently published texts. For example, whereas Werner Breig's lengthy article on Bach in the new edition of Die Musik in Geschichte und Gegenwart briefly mentioned the episode (even though its author, as noted, was also responsible for the most indepth study to date of its eighteenth-century reports), Inge Forst's corresponding entry on Marchand cited only Marpurg by name as the source for the story, in continuation of a long-standing inclination towards his version of events in lifewriting on the French composer. ${ }^{68}$ Recent years have also witnessed a revisiting of the matter of Bach's Brandenburg Concerto No. 5 in relation to this episode, with Pieter Dirksen advancing the intriguing speculation (in part owing to the basis of one of its themes in an organ fugue in $\mathrm{C}$ minor by Marchand) that an earlier version of the work was written expressly for Bach's visit to Dresden to be included in the planned contest, and that it may have even been composed with Volumier in mind as violin soloist. ${ }^{69}$ In the latest editions of Grove's Dictionary, as The New Grove

67 Martin Geck, Bach: Leben und Werk (Reinbek: Rowohlt, 2000), 14; cf. Geck, Johann Sebastian Bach: Life and Work translated by John Hargraves (Orlando, FL: Harcourt, 2006), 6. As the present study demonstrates, Geck's suggestion that "no Bach biography omits an account of Bach's meeting with Louis Marchand" constitutes hyperbole.

68 Werner Breig, "[Bach,] Johann Sebastian," and Inge Forst, "Marchand, Louis," in Die Musik in Geschichte und Gegenwart edited by Ludwig Finscher, 2nd edn. (of publication cited above, n. 61), 26 Vols. (Kassel: Bärenreiter, 1994-2007), Vol. 1, cols. 1397-535, at col. 1404 and Vol. 11, cols. 1045-7, at col. 1046, respectively.

69 Pieter Dirksen, “The Background to Bach's Fifth Brandenburg Concerto," in The Harpsichord and its Repertoire: Proceedings of the International Harpsichord Symposium Utrecht 1990, edited by Pieter Dirksen (Utrecht: STIMU Foundation for Historical Performance Practice, 1992), 157-85, at 178-80. See further, Siegbert Rampe and 
Dictionary and subsequently Oxford Music Online, Edward Higginbottom's essay on Marchand has carried on the historical practice of turning towards the composer's music by way of speculating upon the likely outcome of the competition had it taken place, a tradition that may be traced all the way back to the allusion in the “Nekrolog" to Marchand's Musettes for Christmas Eve. ${ }^{70}$ Discussion of the Quatuor from his posthumously published collection of organ works prompted Higginbottom to conjecture that the "degree of contrapuntal skill shows that Marchand would not have escaped a humiliating defeat at the hands of Bach had he remained to contest the palm". ${ }^{71}$

The twenty-first century, indeed, has witnessed the episode's accruing at least one new national inflection rooted in these same historical ideas, suggesting that the already elaborately formed mythological nexus may be continuing to develop fresh offshoots: consideration of Bach's compositional art, as well as Marchand's, has recently come to the fore in connection with accounts of the story, most extensively in Wolff's landmark biography (2000). As Jolanta T. Pekacz has argued, Wolff's

Michael Zapf, “Neues zu Besetzung und Instrumentarium in Joh. Seb. Bachs Brandenburgischen Konzerten Nr. 4 und 5," Concerto 14/129 (December -January 1997-8): 30-8 and 15/130 (February 1998): 19-22; and Dirksen's response, “Wann komponierte Bach das Fünfte Brandenburgische Konzert?,” Concerto 15/137 (October 1998): 15-17.

70 “The World-Famous Organist, Mr. Johann Sebastian Bach," 301-2.

71 Edward Higginbottom, "Marchand, Louis," in The New Grove Dictionary of Music and Musicians edited by Sadie and Tyrrell, Vol. 15, 820-1, at 821, and online at <http://www.oxfordmusiconline.com/grovemusic/ view/10.1093/gmo/9781561592630.001.0001/omo-9781561592630-e-0000017725>. Neither is Higginbottom's article correct in its assertions that "Only German sources describe this unflattering episode in Marchand's career (principally F.W. Marpurg, J.A. Birnbaum and Jacob Adlung); all agree that Marchand slipped away before the arrival of the celebrated Weimar organist." As discussed, the story is also recounted in two key eighteenth-century English sources; while Marpurg reported one joint performance having taken place prior to Marchand's departure. 
volume is itself responsible for reinscribing, and even advancing, traditional stereotypes such as Bach's intellectualism in a manner more in keeping with the hagiography found in earlier epochs of composer life-writing than with contemporary scholarly biography; amongst various criticisms levelled at its author, Pekacz indicated that he "follows nineteenth-century biographers' footsteps in his proposition that the hero's music and life form an inseparable unity." 72 Consonant with this notion, Wolff's account of Bach's competition with Marchand incorporates parallel contemplation of his subject's music, discussing Bach's assimilation of both French and Italian Baroque idioms, and pointing in particular to these influences in the so-called English Suites (BWV 806-11) composed during this period, by way of conjecturing that he likely performed such pieces exemplifying his familiarity with these styles during his time in Dresden. ${ }^{73}$ In doing so, the German-American musicologist made explicit the connection between this episode and wider issues of nationality not only in Bach's life story but also in his works given the blend of elements of different schools of composition they embodied, not least as a result of his prolonged contact with Italian music during his decade-long tenure at Weimar (1708-17), of which this tale falls towards the end. ${ }^{74}$ Perhaps this same issue lay at

72 Jolanta T. Pekacz, “Memory, History and Meaning: Musical Biography and its Discontents," Journal of Musicological Research 23/1 (2004): 39-80, at 61. As Pekacz noted, the issue of Bach's intellectualism (as well as Wolff's apparent perpetuation of nineteenth-century ideologies of his subject as hero) receives further discussion in John Butt's review of Wolff's biography, “The Saint Johann Sebastian Passion,” The New Republic 223/2-3 (10-17 July 2000): 33-8.

73 Wolff, Johann Sebastian Bach, 181-2.

74 In Wolff's biography (and many other writings that preceded it), the episode of Bach's competition with Marchand is followed more or less straight away by that of his being imprisoned upon his return to Weimar for too forcefully expressing his desire to be released early from his contractual obligations. Wolff, Johann Sebastian Bach, 183-4. 
the roots of Schweitzer's extrapolation of the episode, some decades earlier, to encompass Italian artists as well as French ones, given that the anecdote has become emblematic of the rivalry between different countries and their associated music, above and beyond its two central protagonists. The emergence of what time may reveal to be a new direction for the myth (notwithstanding the potential for intervention in that process yielded by the avenues of enquiry put forward in this chapter) indicates that traces of the political resonances historically embedded within its various retellings have persisted in life-writing on Bach up to the present time, latterly shifting from the national positioning of the author and target readership to that of the subject himself.

Examination of the divergent historical narratives of Bach's contest with Marchand therefore contributes to a greater understanding of the agencies by which biographical myth-making, remarkably, may implicitly permit discrepancies between different versions of the same story to stand unchallenged for some decades. It reveals much about the ways in which the politics of nationality may steer an individual author's portrayal of a given episode concurrently in competing, locally sensitive directions consonant with the writer's own concerns, not merely in terms of their allegiance to one subject or another but also mindful of the country with which the life-writing itself is primarily associated. The development of this particular tale over time also provides illustration of a wider phenomenon in musical biography, identified by Matthew Head in a different context: that in which a revisionist biographer, in attempting to dispel one myth, ultimately succeeds merely 
in introducing another in its place. ${ }^{75}$ As we have seen, although Spitta had intentionally endeavoured to engage with the mythological web that had evolved around this anecdote, its subsequent development demonstrates that he inadvertently became responsible for introducing some of its most elaborate embellishments, taken up by later authors to the extent that over time, they became subsumed within the mythology itself.

Future scholarly engagement with myths and mythology in musical biography may benefit from cultivating approaches that embrace the full spectrum of conflicting versions of a given story for the insights they yield into the cultural values held dear at given times and places, simultaneously casting off the constraints of biography's customary - but now quite outmoded - practices of picking and choosing only those variants that accord with the writer's pursuit of a single holistic truth for the subject. The proposed development of more inclusive, self-reflexive means of critical engagement with myth-making may correspondingly serve better to insulate authors from becoming entangled in the biographical pitfalls of unintentionally furthering the very mythologies they seek to resist. ${ }^{76}$

75 See Matthew Head, "Myths of a Sinful Father: Maynard Solomon's 'Mozart'” (Review-Article), Music $\mathcal{E}$ Letters 80/1 (1999): 74-85. The biography scrutinized in Head's article is Maynard Solomon, Mozart: A Life (London: Hutchinson, 1995). Further discussion on this point is to be found in Pekacz, “Memory, History and Meaning," 44 and Wiley, Re-writing Composers' Lives, Vol. 1, 340-2.

76 I have previously called for more inclusive, self-reflexive practices to be nurtured with respect to modern musical biography in Re-writing Composers' Lives (cited above, n. 1) and in my “Biography and the New Musicology," in (Auto)Biography as a Musicological Discourse edited by Markovic and Mikic, 3-27. 